\title{
Developing Character in Students Based on Conservation Values, Universitas Negeri Semarang
}

\author{
Masrukhi Masrukhi ${ }^{1 *}$, AT. Sugeng Priyanto ${ }^{2}$, Supriyanto Supriyanto ${ }^{3}$, Margi \\ Wahono $^{4}$
}

${ }^{1,3,4}$ Universitas Negeri Semarang, Semarang, Indonesia
${ }^{2}$ Universitas Muhammadiyah Semarang, Semarang, Indonesia
${ }^{*}$ Corresponding author. Email: masrukhi@mail.unnes.ac.id

\begin{abstract}
Universitas Negeri Semarang, which has a vision as a conservation-oriented university with international reputation which was declared in 2010, has an important role in the context of developing the character of its students. The meaning of conservation itself, which does not only have a physical connotation, but also culture and values, is closely related to the UNNES vision. The conservation values implemented by Universitas Negeri Semarang are sourced from three conservation pillars, namely protection, preservation, and sustainable use. The values and culture that are assembled and packaged with these three pillars will provide an important meaning of life that can be the basis for character development in Universitas Negeri Semarang students. Therefore, through this study, students will be formed, character values that can make a very important contribution to the activities of community, nation and state life.
\end{abstract}

Keywords: Character, Conservation, Value.

\section{INTRODUCTION}

Character development is a stage of understanding and shaping one's soul, so that it has its own uniqueness, is interesting, and becomes the identity of every human being. Character education is a process of character development that explores the values contained in every human being, is guided, developed, and directed to be in line with the standards of moral development found in people's lives in general [1].

In the social framework, character development and development is a very basic thing to be done by the nation. Every nation realizes that character development and development is important in order to show the identity of a nation state in international relations. In Indonesia, the process of developing and building character in the context of the nation's character has been echoed by the first president of Indonesia, Bung Karno at the beginning of Indonesia's independence. In a very famous speech related to the development of the nation's character in the early days of independence, "... to build a nationalist character of the Indonesian nation, in the strength of nationalism lies, which will be felt in the future. The Indonesian nation has the spirit of nationalism, the spirit of nationalism must reflecting good things, nationalism that gives birth, nationalism that builds, nationalism that is created and becomes the pride of the Indonesian nation. With good nationalism, the Indonesian people will be able to realize living conditions that have independence in their outer and inner aspects [2].

\section{DEVELOPING CONSERVATION CHARACTER}

Entering life in the era of globalization and during the current COVID-19 epidemic, the big challenge for a student is his ability to maintain his existence and maintain the dignity of his nation and country so that he becomes a nation and country that is respected and has an identity. This must be done because in an era like today, national identity is an important thing in international relations. Indonesia as a nation state, has a strategic role in international relations.

The above needs to be done, because the symptoms of the declining nature of idealism and a sense of nationalism among students as the next generation are starting to appear with the dominance of the culture of capitalism and liberalism entering various spheres of life. A study conducted by the author in 2011, showed that students' styles, which were divided into five kinds of groups. The first group is the confrontational idealist group, namely students who are active in activities to fight stability through student organizations and demonstration activities. The second group is the realistic idealist group, which is a group of students who prefer to take cooperative action in their struggle to face stability. Third, opportunist groups are students who tend 
to be more in favor of the government. The fourth is a professional group, a group of students who focus on their activities as students, namely carrying out lecture activities in class. Fifth, is a recreational group, namely a group of students who tend to have a glamorous lifestyle and a life that tends to aim at mere pleasure.

Therefore, campuses need to realize this, with a focus on maintaining and developing ideals, and reconstructing student roles and responsibilities in various aspects. Students must have an awareness of the importance of having and believing in a value and moral system that is the basis for them when they are active, acting as agents of change to realize future ideals for themselves and the glorious Indonesian nation.

Becoming a campus with a conservation perspective is the vision of the Universitas Negeri Semarang which has a deep meaning for the development of the campus in the future. Conservation is not only concerned with activities that are nature management, but also with regard to cultural preservation, human relations with humans, humans with the natural surroundings, and the application of values in various aspects of life. In language studies, the word conservation comes from 2 syllables, namely con means together and save/servare means trying to keep something they have consistently and sustainably. In this case, there are 3 activities that can be done to carry out a conservation, these activities include saving, learning, and applying, in order to create an atmosphere and conditions that are harmonious, harmonious, and balanced in life and life.

In the context of the 3 activities of implementing conservation, the implementation of the values of rights and obligations becomes an important pillar for humans, namely what humans get must be accompanied by what they will get. The balance between obligations and rights is not only in terms of economic activity, but also the interaction between fellow humans and humans with the natural surroundings. enjoying oxygen from the air provided by nature, feeling the pleasure of the coolness of nature, enjoying the charm of nature that is side by side in front of humans is a right that we get from the universe. Therefore, in return, as humans as partners of nature who have provided various means and infrastructure of life, we must maintain, protect, and preserve nature as best we can, one of which is conservation activities in several areas of life.

The balance of obligations and rights carried out is an interesting part of a life process. When affection, responsibility, care, love, wisdom, courtesy, have been manifested in students' daily lives through the relationship between students and the universe, plants, animals that live around students, water, air. Departing from the beauty of the preservation values, it will grow the breath of spirituality. They are not only responsible and concerned for the survival of the universe, but also for the creator of the universe. This is as expressed by Thomas Lickona, namely self-values as moral knowledge, moral feelings, and moral actions.
Borrowing the term put forward by Schopenhauer, caring and loving in the Indonesian context is called compassion, namely a growing sense of affection, care, and sympathy. According to him, the feeling of love and affection is not only mundane, but more than that. Schopenhauer calls it the allencompassing oneness, which is the true identity for man. At this level, Schopenhauer refers to metaphysical awareness, namely the sense of love and care that humans have for the environment based on "trust divine". Humans who have reached this level, will carry out maintenance, protection, and preservation actions based on awareness of the existence of orders from God. then gave birth to universal human values.

Mutual awareness of students to the value of conservation in students must be maintained and developed as a backdrop for them to live in society in the future after completing their studies. One day after they finish their studies from the Universitas Negeri Semarang, they will take on the role of becoming reliable conservation cadres, who understand and are willing to serve the community through the implementation of conservation values that they understand and model for the surrounding community. Cultivating collective awareness is part of a comprehensive effort, with a variety of approaches. If referring to the moral analysis theory expressed by Kurtines, there are several approaches that can be used as a means of fostering conservation awareness for students, namely the development of students' moral knowledge, developing good attitudes in students, and developing student behavior based on moral values prevailing in the school. Public.

The first thing to do is that there must be an effort to change the mindset of students, so they can understand the importance of implementing conservation values in daily life, both on campus and off campus. According to the Cognitive Moral Development approach, by understanding and trying to maintain the values of students, it is hoped that the awareness and willingness of students will emerge to internalize these values into themselves. Awareness and the internalization of values into themselves which is preceded by a process to understand what is contained in these values (cognitive structure) will have strong originality, as a result of the process of knowing and understanding (learning behavior). The inclusion of conservation education courses in the curriculum that applies to all faculties and study programs, such as what was done by the Universitas Negeri Semarang which made the Conservation Education course a compulsory subject for students to be the right policy to create mutual awareness so that the conservation value conveyed in formal lectures, students can apply in everyday life.

Through changes in the structure of cognition, apart from developing character, which is no less important is through an intuitive approach. The intuitive approach is carried out by bringing students to the imagination and mood of conservation values. In the 
Affective Moral Development approach, it is highly recommended to inculcate affective values such as feelings, intuition, and imagination. This development process requires careful planning, which is different from the cognitive development process. Leaders and lecturers are required to have the ability to manage this approach. Methods in accordance with this approach can be applied in the lecture process so that it is in line with the learning objectives to be achieved.

Furthermore, the Moral Behavior Development approach, an approach that considers more aspects internalized through the process of habituation (habituation). Although initially the Moral Behavior Development approach emerged from an experiment conducted by Ivan Pavlov on animals, this approach is very relevant to efforts to internalize values, especially conservation values. The habituation process carried out for a student to behave in an orderly and good manner in everyday life both on campus and outside campus, will get used to doing it even without any orders. In turn, the habit of carrying out orderly behavior and good behavior will settle into its property value in itself. When they act outside the character values prevailing in society, they will immediately realize that they will feel guilty.

All of the above approaches will have a better level of effectiveness if they are carried out simultaneously. This means that character development (character building) is comprehensive or comprehensive, consisting of an emotional touch, cognitive structure, and the creation of an environment that supports the inculcation of conservation values in students. Campus managers must be able to open a dialogue room with students as one of the stakeholders. Through dialogues carried out between campus administrators and students, both formal dialogues through a discussion forum and informally through various media channels, they generally claim to feel proud of the preservation of the university. The pride they express is one indication of the magnitude of the collective awareness of conservation among them. This must be addressed by the campus leadership as an opportunity to further increase awareness and understanding of conservation values in students.

All matters related to character development in students based on conservation values at the Universitas Negeri Semarang are important to be carried out by the Universitas Negeri Semarang, especially in an era like the current one. Preparing students to understand, realize and make them agents of conservation values in the community must be a mutual agreement so that not only students have good character, but they can spread it to the wider community.

\section{STUDENT EMPOWERMENT ACTIVITIES UNIT}

Character development in students based on conservation values at the Universitas Negeri Semarang is not only done through curricular activities, but can also be done through extracurricular activities which in this case can be carried out by intra-campus student organizations at UNNES through the Student Activity Unit (UKM). UNNES has student organizations and student activity units in various fields that students can use to develop their potential to support the development of conservation values. To meet the service standards that have been determined by campus managers in fostering and developing students, Universitas Negeri Semarang has a very large number of Student Activity Units (UKM).

Through student activity units (UKM) students will be able to carry out their activities outside of study hours to develop their reasoning, interests, talents, and skills. To achieve the goal of developing conservation character values, there needs to be a joint effort made by campus leaders, students and also the administrators of student activity units. The shared vision is formulated by the university leadership together with students and is understood by all campus residents. UNNES develops a common vision, as a healthy, superior, and prosperous international conservation university. This vision has been well socialized to all UNNES residents, starting from the elements of leadership, lecturers, students, to the next permanent employee. The involvement of all campus residents in fostering the Student Activity Unit will have a good impact on the efforts made by the Universitas Negeri Semarang to grow and develop character and conservation values in students through activities carried out by ORMAWA and also the Student Activity Unit. The success of ORMAWA and the Student Activity Unit as a vehicle for the development of conservation values apart from curricular activities depends on the planning and readiness of all parties involved.

The student activity unit is one of the media or vehicles that can be used to develop the character of Universitas Negeri Semarang students because it is in accordance with the objectives of UKM as a developer of students' reasoning, interests, talents, and arts. Conservation characters or values can be incorporated into non-curricular activities such as SMEs.

\section{CONCLUSION}

Character development in students based on conservation values at the Universitas Negeri Semarang is important to support the vision of the Universitas Negeri Semarang as a campus with a conservation perspective and with an international reputation. All matters related to character development in students based on conservation values, Universitas Negeri Semarang are important to be done by Universitas Negeri Semarang in order to form students who are able to implement conservation values who will become agents of planting conservation values in society, nation and state. 


\section{ACKNOWLEDGMENT}

We would thanks to Universitas Negeri Semarang and Universitas Muhammadiyah Semarang for supporting the completion of this article.

\section{REFERENCES}

[1]. Kurtines, Willian M. 2004. Morality, Moral Behavior, and Moral Development. New York: John Wiley \& Sons.

[2]. Sukarno. (1930). Indonesia Sues Bung Karno's Defense Speech; Before a Colonial Judge in 1930. Jakarta: Ministry of Information R 